\title{
Williams-Campbell Syndrome Diagnosed in
Adulthood: A Rare Entity of Bronchiectasis
}

\author{
Yetişkinlikte Tanı Alan Williams-Campbell Sendromu: Nadir Bir Bronşektazi
}

Kübra Gül Kılınçarslan', Fatma Tokgöz Akyıl', Neslihan Boyracı', Metin Sucu², Melih Akay Arslan', Hülya Abalı', Kaan Kara', Seda Tural Önür'

\section{Abstract}

Williams-Campbell syndrome is a rare condition caused by a deficiency or complete absence of bronchial wall cartilage formation, resulting in distal airway collapse and bronchiectasis. The syndrome, generally encountered first during infancy, progresses with recurrent pneumonia with such obstructive symptoms as cough and wheezing from childhood onwards, while adult cases are rarely reported. A 40year-old male patient presented with complaints of shortness of breath, cough and fever for one week. He was hospitalized with a diagnosis of bronchiectasis exacerbation due to elevated infection parameters, when radiology revealed extensive cystic bronchiectasis, air trapping and airway collapse at expiration. After excluding other etiologies, the patient was diagnosed with Williams-Campbell syndrome in light of the clinical and radiologic findings. He was discharged following clinical response and started on a pulmonary rehabilitation program, was referred to a lung transplantation clinic. The case is representative of the set of rare adult cases showing that WilliamsCampbell syndrome can be diagnosed in adulthood, and signaling that the etiology of bronchiectasis should be further evaluated in advanced ages.

Key words: Williams-campbell syndrome, bronchiectasis, congenital anomaly.

\section{Özet}

Williams-Campbell sendromu, bronş duvarı kartilaj oluşum eksikliğinden veya tamamen yokluğundan kaynaklanan, distal hava yolu kollapsı ve bronşektaziye neden olan nadir bir sendromdur. Sendrom ilk olarak infant dönemde tanımlanmıs olup çocukluk döneminden itibaren, öksürük wheezing gibi obstrüktif semptomlar ve tekrarlayan pnömoniler ile seyreder. Erişkin yaşta olgular çok nadir bildirilmiştir. Kırk yaşında erkek hasta, bir haftadır giderek artan nefes darlığı, öksürük, ateş şikayetleriyle başvurdu. On yıldır bronşektazi tanısı olan hastanın yılda birkaç kez enfeksiyon geçirme öyküsü mevcuttu. Enfeksiyon parametrelerinde yükseklik saptanan hasta enfekte bronşektazi tanısı ile yatırıldı. Inspiryumda ve ekspiryumda çekilen tomografilerde yoğun hava hapsi, ekspiryumda hava yolu kollapsı izlenen hastanın kistik bronşiektazi etyolojisi araştırıldı. Galaktomannan antijeni negatifti, immünglobulin düzeyleri ve alfa 1 antitripsin değerleri normal sınırlarda saptandı. Hastaya klinik ve radyolojik bulgular eşliğinde WilliamsCampbell sendromu tanısı konuldu. Antibiyoterapi sonrası klinik yanıt alınan hasta pulmoner rehabilitasyon programına alınarak akciğer nakli açısından değerlendirilmek üzere yönlendirildi. Sonuç olarak, Williams-Campbell sendromu erişkin yaşta da tanı konulabilen nadir bir sendromdur ve tüm yaşlarda bronşektazi etyolojisinin araştırılması hasta yönetimine katkı sağlayacaktır.

Anahtar Sözcükler: Williams-campbell sendromu, bronşiektazi, konjenital anomali.
'Department of Chest Diseases, Yedikule Chest Diseases and Thoracic Surgery Training and Research Hospital, İstanbul, Turkey

${ }^{2}$ Department of Radiology, Kadıköy Florence Nightingale Hospital, İstanbul, Turkey
'Yedikule Göğüs Hastalıkları ve Göğüs Cerrahisi Eğitim ve Araştırma Hastanesi, Göğüs Hastalıkları Bölümü, İstanbul

${ }^{2}$ Kadıköy Florence Nightingale Hastanesi, Radyoloji Bölümü, İstanbul

Submitted (Başvuru tarihi): 29.07.2021 Accepted (Kabul tarihi): 21.09 .2021

Correspondence (iletişim): Kübra Gül Kılınçarslan, Department of Chest Diseases, Yedikule Chest Diseases and Thoracic Surgery Training and Research Hospital, İstanbul, Turkey

e-mail: kbragl28@gmail.com 
Williams-Campbell syndrome is a rare form of congenital cystic bronchiectasis caused by a deficiency or complete absence of cartilage formation in the bronchi. The lack of cartilage causes the distal airways to collapse and bronchiectasis to occur (1). The defect is often present in the 4th-6th row segment bronchi, but may also extend between the 1st and 8th segment bronchi (2). Symptoms and prognosis depend on the degree of development of the bronchial cartilages. Although it usually presents at an early age, adult patients have recently been defined after presenting with wheezing and coughing (3). The prevalence of bronchiectasis is $701 / 100,000$, while clear data on the incidence of Williams-Campbell syndrome is lacking, being very rare in the etiology of bronchiectasis (4). Clinical history, characteristic expiratory airway collapse on radiological examination, and other causes of congenital and acquired bronchiectasis should be excluded for diagnosis. Although a lack of cartilage plates in the affected bronchi can be demonstrated histopathologically by bronchoscopic or surgical biopsies, it is not performed in all cases due to a failure in diagnosis and the complication risks involved (5). This syndrome is very rare, and is most frequently reported in childhood and young adults. We present here the case of a 40-year old adult diagnosed with Williams-Campbell syndrome, with extensive cystic bronchiectasis and a history of recurrent infections.

\section{CASE}

A 40-year old male was admitted to our clinic with infected bronchiectasis. The patient had complaints of increased foul-smelling sputum, cough and dyspnea continuing for one week. The patient was a never smoker and had no additional diseases, and had a history of antibiotic use several times a year for 5 years, with a few episodes of exacerbation requiring hospitalization each year. The patient had been under long-term oxygen treatment for three years. His arterial blood pressure was $120 / 70 \mathrm{mmHg}$, heart rate was $88 / \mathrm{min}$, body temperature was $37.7^{\circ} \mathrm{C}$, respiratory rate was $18 / \mathrm{min}$, and oxygen saturation was $88 \%$ by pulse oximetry. A respiratory system examination revealed crackles in the middle and lower areas of both lungs.

Laboratory examinations revealed elevated white blood cell count $\left(13.4 / \mathrm{mm}^{3}\right)$ and C-reactive protein $(77.4 \mathrm{mg} / \mathrm{L}$, normal range: $0-5)$, while other blood count parameters and biochemistry tests were within the normal range. Bilateral diffuse cystic bronchiectasis was detected in a postero-anterior (PA) chest $X$-ray (Figure 1) and thorax high-resolution computed tomography (HRCT). Empirical cephalosporin (2 g/day) and clindamycin (4x600 mg) antibiotic therapy was initiated and microbiological samples were taken. E. coli was reproduced in a sputum culture. Three sputum tests for acid-fast bacilli (AFB) bacillus and fungal cultures yielded no microorganisms. Galactomannan antigen was negative in blood and sputum. Clinical response from the third day of treatment was observed.

The patient had no history of tuberculosis or severe childhood infection, though thorax computed tomography (CT) revealed widespread cystic bronchiectasis. Immunoglobulin and alpha-1 antitrypsin levels were within normal ranges. Immunoglobulin G level was $27.4 \mathrm{mg} / \mathrm{dl}$ (normal range: 7-16), immunoglobulin A was $3.0 \mathrm{mg} / \mathrm{dl}$ (normal range: $0.7-4$ ), immunoglobulin $M$ was $1.37 \mathrm{mg} / \mathrm{dl}$ (normal range: 0.4-2.3), total immunoglobulin $E$ was 402 $\mathrm{kU} / \mathrm{L}$ (normal range: <102) and alpha-1 antitrypsin level was $1.51 \mathrm{~g} / \mathrm{L}$ (normal range: 0.9-2). A test for human immunodeficiency virus was negative, and total blood count revealed no peripheral eosinophilia. Clinical and radiological findings demonstrated no signs of sinusitis, rhinitis or ear problems. Cardiac examination was normal Cystic fibrosis had been excluded previously in another center. Radiologically, Mounier-Kuhn syndrome was not considered due to the normal diameters of the trachea and the main bronchus. An expiratory HRCT was performed for comparison with an inspiratory tomography scan, and extensive airway collapse was noted in the expiratory HRCT. Tomography revealed symmetrical, central cystic bronchiectasis areas with secretion materials and fluid levels in the right lung middle lobe, in the left lung lingular segment and in both lower lobes, while air trapping and mosaic pattern were present especially in the lateral basal and postero-basal segments of the right lung (Figure $2 a$ and b). Based on the clinical and radiological findings, the patient was diagnosed with WilliamsCampbell syndrome. His family history revealed that his sister had a similarly frequent pulmonary infection and had been diagnosed with bronchiectasis. The sister was duly informed about the possibility of the presence of the same syndrome.

After two weeks of antibiotic treatment, the patient was discharged following clinical and laboratory response. A pulmonary rehabilitation program was planned and the patient was referred to a lung transplantation clinic for evaluation.

Written informed consent was obtained from the patient for this case report and all accompanying images. 


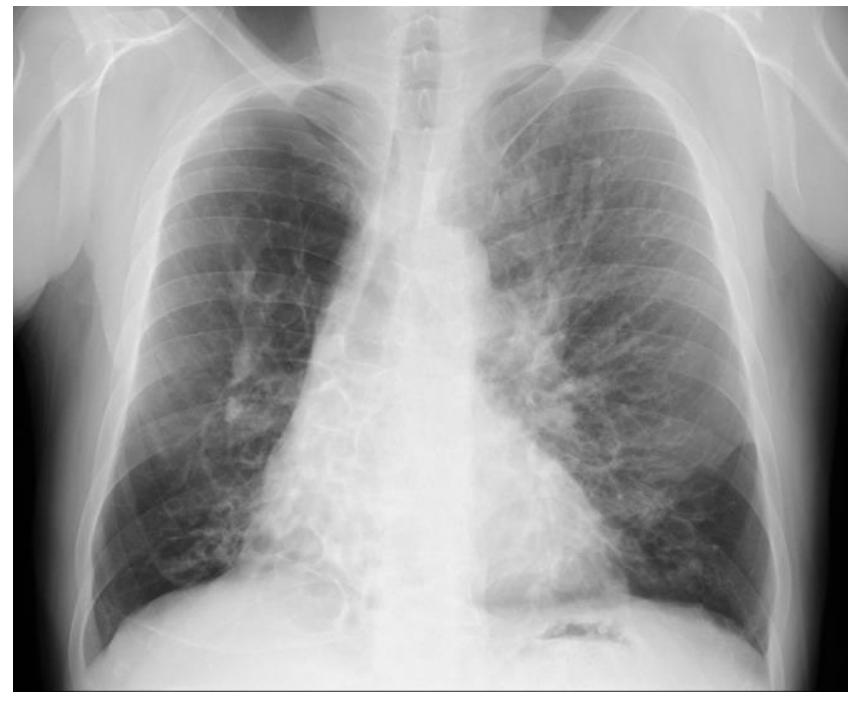

Figure 1: Chest $X$-ray at presentation

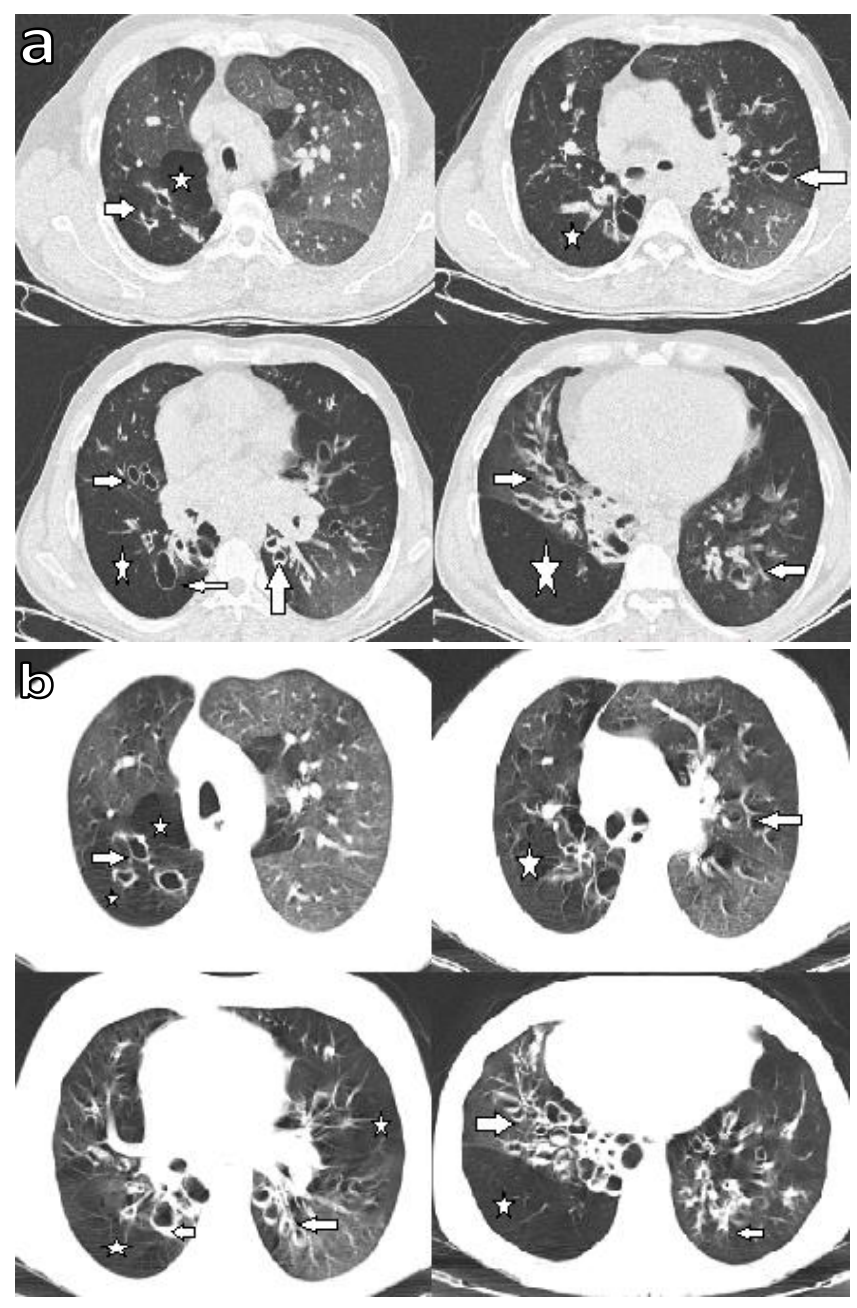

Figure 2a and b: Expiratory HRCT showing bilateral diffuse bronchiectasis (arrows) and air trapping (asterisk) (a), Thorax CT showing bilateral diffuse bronchiectasis (arrows) and air trapping (asterisk) (b)

\section{DISCUSSION}

The presented case concerns a middle-aged male patient, implicating that the underlying etiology of bronchiectasis at an advanced age could be understated in its present form. Our patient's history of multiple hospital admissions with frequent pulmonary infections is significant in terms of its potential contribution to the understanding of the etiology of bronchiectasis.

Williams-Campbell Syndrome is mainly described in infants, and progresses with obstructive symptoms such as cough, wheezing and recurrent pneumonia starting from childhood $(3,5)$, while reported adult cases are extremely rare. Konoglou et al. (6) reported a 57-year-old female patient diagnosed with Williams-Campbell Syndrome with clinical and radiological findings.

Radiologically, bilateral cylindrical or cystic bronchiectasis and hyperinflation distal to the bronchiectasis are significant. At the involved bronchi, expiratory collapse and airway trapping in the distal part become evident. Inadequate clearance of the bronchial tree and the mucus generated as a result of segmental and lobar collapse can lead to lung parenchyma damage (7). The distribution of bronchiectasis may be important in a differential diagnosis. The central distribution is suggestive of allergic bronchopulmonary aspergillosis; a dominant upper lobe distribution is seen in cystic fibrosis; central and lower lobe distributions are consistent with primary ciliary dyskinesia; left upper lobe lingular segment involvement is characteristic of non-tuberculous mycobacteria; and lower lobe involvement is typically consistent with idiopathic bronchiectasis (8). In our case, the cystic bronchiectasis was more predominant in the lower lobes. Galactomannan antigen and immunoglobulin values were normal, and no microbiological agent was grown. Cystic fibrosis had been previously excluded, and the clinical findings were inconsistent with primary ciliary dyskinesia. The patient's radiological findings were compatible with Williams-Campbell Syndrome. Although a bronchoscopic biopsy may confirm the absence of cartilage plaques in the affected bronchi histopathologically, lung biopsy has several complications and may not always be diagnostic. Today, radiological imaging is the most preferred diagnostic tool (9). Di Scioscio et al. (10) presented a case of Williams-Campbell Syndrome in 2006 with bilateral cylindrical and cystic ballooning and bronchiectasis in the distal bronchus on inspiratory and expiratory CT scans. George et al. (11) also determined collapsed subsegmental bronchi from virtual bronchoscopy with threedimensional CT in the same year. Bronchoscopy was not performed in our case due to the presence of severe infection. As the patient declined the procedure, the diagnosis was based on the exclusion of other probable 
causes of bronchiectasis, and was confirmed with compatible radiological findings.

In a recent case report by Rohilla et al. (12) detailing diffuse bronchiectasis in a 62-year-old patient, MounierKuhn syndrome, bronchial cyst, tracheo-esophageal fistula, pulmonary artery aneurysm and pulmonary sequestration were excluded radiologically; and immunoglobulin levels and alpha- 1 antitrypsin serum levels, and tests for allergic bronchopulmonary aspergillosis, were all detected as normal. After ruling out the other common causes of bronchiectasis, the patient was diagnosed with Williams-Campbell syndrome. In the present study, our case was similarly diagnosed in adulthood after the exclusion of a bronchiectasis etiology. Genetic transmission and familial cases have been reported in Williams-Campbell syndrome (6). The fact that the sibling of our patient was also found to have similar bronchiectasis suggested familial transmission, although she lived in a different city and so was unable to attend our clinic for further evaluation.

To date, no specific established treatment has been defined, with the main treatment being based on the prevention of exacerbations $(13,14)$. Exercise and the strengthening of the respiratory muscles have been suggested to be beneficial in patients with bronchiectasis other than cystic fibrosis (15). Oxygen therapy is required in patients needing supplemental oxygen (13). It is suggested that surgical resection should be considered only in patients with localized disease or at bleeding risk (16). Our case had been under long-term oxygen treatment, and so a pulmonary rehabilitation program was initiated. In 1998, Palmer et al. (1) performed lung transplantation on a case with Williams-Campbell syndrome, however the patient was lost to respiratory infection in the first year. Burguete et al. (16) reported successful lung transplantation in a 31-year old male patient who survived longer than 10 years. That said, a careful evaluation prior to lung transplantation is recommended in patients with Williams-Campbell syndrome (17). Our patient was informed about the syndrome, was started on a pulmonary rehabilitation program and was referred for evaluation for lung transplantation.

In conclusion, Williams-Campbell syndrome is a rare syndrome that may be diagnosed in adulthood, despite the overwhelming focus on children in previous literature and in practice. We believe that the etiology of bronchiectasis should be investigated even in those of advanced age to support better diagnostic and treatment prospects.

\section{CONFLICTS OF INTEREST}

None declared.

\section{AUTHOR CONTRIBUTIONS}

Concept - K.G.K., F.T.A., N.B., M.S., M.A.A., H.A., K.K., S.T.Ö.; Planning and Design - K.G.K., F.T.A., N.B., M.S., M.A.A., H.A., K.K., S.T.Ö.; Supervision - K.G.K., F.T.A., N.B., M.S., M.A.A., H.A., K.K., S.T.Ö.; Funding - K.G.K., F.T.A.; Materials - K.G.K., F.T.A., S.T.Ö.; Data Collection and/or Processing - K.G.K., F.T.A., S.T.Ö.; Analysis and/or Interpretation - K.G.K., F.T.A.; Literature Review K.G.K., F.T.A., S.T.Ö.; Writing - K.G.K., F.T.A.; Critical Review - S.T.Ö.

\section{YAZAR KATKILARI}

Fikir - K.G.K., F.T.A., N.B., M.S., M.A.A., H.A., K.K., S.T.Ö.; Tasarım ve Dizayn - K.G.K., F.T.A., N.B., M.S., M.A.A., H.A., K.K., S.T.Ö.; Denetleme - K.G.K., F.T.A., N.B., M.S., M.A.A., H.A., K.K., S.T.Ö.; Kaynaklar K.G.K., F.T.A.; Malzemeler - K.G.K., F.T.A., S.T.Ö.; Veri Toplama ve/veya İşleme - K.G.K., F.T.A., S.T.Ö.; Analiz ve/veya Yorum - K.G.K., F.T.A.; Literatür Taraması K.G.K., F.T.A., S.T.Ö.; Yazıyı Yazan - K.G.K., F.T.A.; Eleştirel İnceleme - S.T.Ö.

\section{REFERENCES}

1. Palmer SM Jr, Layish DT, Kussin PS, Oury T, Davis RD, Tapson VF. Lung transplantation for Williams-Campbell syndrome. Chest 1998; 113:534-7. [CrossRef]

2. Watanabe $Y$, Nishiyama $Y$, Kanayama $H$, Enomoto $K$, Kato K, Takeichi M. Congenital bronchiectasis due to cartilage deficiency: CT demonstration. J Comput Assist Tomogr 1987; 11:701-3. [CrossRef]

3. Amano S, Yoshida Y, Shimizu H, Takeda T, Urabe N, Mizoo A, et al. An adult case of Williams-Campbell syndrome associated with pulmonary hypertension and a severe decrease in ventilatory response. Nihon Kyobu Shikkan Gakkai Zasshi. 1997; 35:1265-70.

4. Henkle E, Chan B, Curtis JR, Aksamit TR, Daley CL, Winthrop KL. Characteristics and health-care utilization history of patients with bronchiectasis in US medicare enrollees with prescription drug plans, 2006 to 2014. Chest 2018; 154:1311-20. [CrossRef]

5. Kaneko K, Kudo S, Tashiro M, Kishikawa T, Nakanishi Y, Yamada $\mathrm{H}$. Case report: computed tomography findings in Williams-Campbell syndrome. J Thorac Imaging 1991; 6:11-3. [CrossRef]

6. Konoglou, Porpodis K, Zarogoulidis P, Loridas N, Katsikogiannis N, Mitrakas A, et al. Williams-Campbell synd- 
rome: a case report. Int J Gen Med 2012; 5:41-4. [CrossRef]

8. Noriega Aldave AP, William Saliski D. The clinical manifestations, diagnosis and management of williamscampbell syndrome. N Am J Med Sci 2014; 6: 429-32. [CrossRef]

9. McAdams HP, Erasmus J. Chest case of the day. Williams-Campbell syndrome. AJR Am J Roentgenol 1995; 165:190-1. [CrossRef]

10. Di Scioscio V, Zompatori M, Mistura I, Montanari P, Santilli $L$, Luccaroni $R$, et al. The role of spiral multidetector dynamic CT in the study of WilliamsCampbell Syndrome. Acta Radiol 2006;47:798800. [CrossRef]

11. George J, Jain R, Tariq SM. CT bronchoscopy in the diagnosis of Williams-Campbell syndrome. Respirology 2006; 11:117-9. [CrossRef]

12. Rohilla M, Previgliano C, Geimadi A, Sangster G. Williams-Campbell syndrome: an unusual presentation in an adult patient. BJR Case Rep 2020; 7 : 20200052. [CrossRef]

13. Rosen MJ. Chronic cough due to bronchiectasis: ACCP evidence-based clinical practice guidelines. Chest 2006; 129:122S-131S. [CrossRef]
7. Marom EM, Goodman PC, McAdams HP. Focal abnormalities of the trachea and main bronchi. AJR Am J Roentgenol 2001; 176: 707-11. [CrossRef]

14. Przerwa KB, Bestry I, Gawryluk D, Wiatr E. Case report: Williams Campbell syndrome. Pol J Radiol 2009; 74:76-8.

15. Ten Hacken NH, Kerstjens HA. Bronchiectasis. Clin Evid (Online) 2011; 2011 . Pii: 1507.

16. Burguete SR, Levine SM, Restrepo MI, Angel LF, Levine DJ, Coalson JJ, et al. Lung transplantation for Williams-Campbell syndrome with a probable familial association. Respir Care 2012; 57:1505-8. [CrossRef]

17. Orens JB, Estenne M, Arcasoy S, Conte JV, Corris P, Egan JJ, et al; Pulmonary Scientific Council of the International Society for Heart and Lung Transplantation. International guidelines for the selection of lung transplant candidates: 2006 update - a consensus report from the Pulmonary Scientifi c Council of the International Society for Heart and Lung Transplantation. J Heart Lung Transplant 2006; 25:745-55. [CrossRef] 